\title{
ANALISIS FAKTOR YANG MEMPENGARUHI CAREER PLATEAU (KEMANDEGAN KARIR) GURU PADA SMPN 1 DENPASAR
}

\author{
I Nyoman Bagus Tri Permana Putra ${ }^{1}$, Lulup Endah Tripalupi ${ }^{2}$ \\ Jurusan Pendidikan Ekonomi \\ Universitas Pendidikan Ganesha \\ Singaraja, Indonesia ${ }^{1,2}$ \\ e-mail: permanaputra32@gmail.com¹, lulup_tripalupi@yahoo.com²,
}

\begin{abstract}
Abstrak
Penelitian ini bertujuan untuk mengetahui faktor-faktor yang mempengaruhi career plateau (kemandegan karir) guru pada SMPN 1 Denpasar, dan faktor yang paling dominan mempengaruhi career plateau (kemandegan karir) guru pada SMPN 1 Denpasar. Penelitian ini dilaksanakan di SMPN 1 Denpasar dengan jumlah responden sebanyak 38 orang. Data yang dikumpulkan dengan metode kuesioner, dianalisis dengan analisis faktor melalui Statistical Program Social Scence (SPSS) 16.0 for windows. Hasil penelitian menunjukkan bahwa terdapat delapan faktor yang mempengaruhi career plateau kemandegan karir guru pada SMPN 1 Denpasar, yaitu faktor usia, faktor lama bekerja, faktor tingkat pendidikan, faktor keinginan belajar, faktor eksplorasi karir, faktor keterlibatan bekerja, faktor dukungan atasan dan faktor gaji atau upah. Faktor usia, faktor lama bekerja, dan faktor tingkat pendidikan menjadi faktor yang dominan yang memiliki variance explained tertinggi yaitu masing-masing sebesar $31,205 \%$, $17,818 \%$ dan $13,709 \%$, artinya total nilai varianced explained dari ketiga faktor keseluruhan mampu mempengaruhi career plateau (kemandegan karir) guru pada SMPN 1 Denpasar sebesar $62.732 \%$.
\end{abstract}

Kata kunci: kemandegan karir guru

\begin{abstract}
This study aims to find the factors that influence the teacher's career plateau in SMPN 1 Denpasar, and the most dominant factor influencing the teacher's career plateau in SMPN 1 Denpasar. This research was conducted in SMPN 1 Denpasar, involving of 38 people as the respondents. Data were collected by questionnaire, were analyzed by factor analysis through Social Scence Statistical Program (SPSS) 16.0 for Windows. The results of this study showed that there were eight factors which influence the teacher career plateau in SMPN 1 Denpasar, namely the age, the period to work's, level of education, motivation to study, career exploration, involved to the work, support from head master, and salary factor's. Age factor, the period to work factor, and level of education factor became the most dominant factor that has the highest explained variance in the amounted of $31,205 \%, 17,818 \%$ and $13,709 \%$, meaning that the total value of the three factors influence varianced overall the teacher career plateau in SMPN 1 Denpasar of $62.732 \%$.
\end{abstract}

Keywords: teacher's career plateau

\section{PENDAHULUAN}

Sebuah peraturan tentang jabatan fungsional dan angka kredit untuk kenaikan pangkat/golongan Pegawai Negeri Sipil (PNS) khususnya guru mengalami perubahan. Perubahan peraturan yang sudah berlaku mulai Januari 2013 ini dapat dilihat dari pemberian pangkat/golongan ruang yang mempunyai empat tingkatan yaitu, golongan III/a-III/b dengan sebutan guru pertama, golongan III/C-III/d dengan sebutan guru muda, golongan IV/a-IV/c dengan sebutan guru madya, dan golongan IV/d-IV/e dengan sebutan guru utama. Selain itu, peraturan ini juga menyebutkan bahwa kenaikan setiap pangkat/golongan dimulai dari III/b hingga pangkat/golongan IV/e mensyaratkan adanya angka kredit dari unsur publikasi 
yang harus diperoleh melalui kegiatan penulisan karya tulis ilmiah dan minimal berada pada pangkat/golongan sebelumnya adalah 4 tahun.

Dilihat dari perubahan yang terjadi, maka guru-guru akan merasa bahwa peraturan ini akan lebih menyulitkan untuk melakukan kenaikan pangkat. Karena kenaikan pangkat dari jenjang $\mathrm{III} / \mathrm{b}$ ke tingkat yang lebih tinggi mewajibkan guru untuk melakukan Pengembangan Keprofesian Berkelanjutan (PKB).

Pengembangan keprofesian berkelanjutan ini merupakan bagian dari unsur tugas utama guru yang harus dikerjakan agar dapat naik jabatan ke tingkat yang lebih tinggi dan bertujuan untuk meningkatkan kualitas layanan pendidikan di sekolah/madrasah dalam rangka meningkatkan mutu pendidikan. Adapun bagian dari pengembangan keprofesian berkelanjutan meliputi a) pengembangan diri berupa diklat fungsional, dan kegiatan kolektif guru, b) publikasi ilmiah berupa hasil penelitian atau gagasan inovatif, serta buku teks pelajaran, buku pengayaan, dan pedoman guru, c) karya inovatif berupa penemukan/penciptaan teknologi tepat guna, karya seni, membuat/memodifikasi alat pengajaran, serta mengikuti pengembangan penyusunan soal.

Kenaikan pangkat/golongan yang peraturannya mengalami perubahan tersebut di atas merupakan sebuah perkembangan karir yang dimiliki oleh Pegawai Negeri Sipil (PNS) khususnya guru selama meniti karirnya di dunia pendidikan. Karir merupakan perkembangan para pegawai secara individual dalam jenjang jabatan atau kepangkatan yang dapat dicapai selama masa kerja dalam suatu organisasi. Karir juga menunjukkan suatu rangkaian perubahan sikap dan perilaku serta motivasi yang terjadi pada setiap individu selama rentang waktu kehidupannya. Menurut Handoko (2001:129), "karir adalah semua pekerjaan atau jabatan yang ditangani atau dipegang selama kehidupan kerja seseorang". Menurut Simamora (2001:504), "karir merupakan urutan-urutan posisi atau jabatan yang diduduki oleh seseorang selama hidupnya". Setiap orang dalam meniti karirnya melalui empat tahapan karir adalah sebagai berikut. 1) Tahap penempatan (establishment) terjadi pada permulaan karir dalam melilih jenis pekerjaan yang akan digelutinya, 2) tahapan kemajuan (advancement) merupakan periode bergerak seseorang untuk menemukan bidang pekerjaan yang dianggapnya tepat setelah pernah mengalami satu atau dua kesalahan dalam pekerjaanya, 3)tahap pemeliharaan (maintenance) terjadi jika individu telah mencapai batas kemajuan sehingga individu tersebut akan cendrung berkonsentrasi pada pekerjaan yang digelutinya sekarang untuk bersaing dengan tenaga kerja yang lebih muda, dan 4) tahap kemunduran (withdrawal) tahap pada suatu titik sebelum individu pensiun yang sesungguhnya.

Menurut Handoko (2001:133), "pengembangan karir adalah peningkatanpeningkatan pribadi yang dilakukan seseorang untuk mencapai suatu rencana karir". Pengembangan karir sangat diharapkan oleh setiap pegawai, karena dengan pengembangan ini akan mendapatkan hak-hak yang lebih baik dari apa yang diperoleh sebelumnya baik material maupun non material, misalnya kenaikan pendapatan, perbaikan fasilitas, dan sebagainya. Sedangkan hak-hak yang tidak bersifat material misalnya status sosial, perasaan bangga dan sebagainya. Pengembangan karir yang dilaksanakan dan dikembangkan pada pegawai negeri sipil, melalui pembinaan karir dan penilaian sistem prestasi kerja dan sistem karir pada umumnya melalui kenaikan pangkat, mutasi jabatan serta pengangkatan dalam jabatan. Oleh sebab itu, setiap pegawai dalam meniti karirnya, diperlukan adanya perencanaan karir yang tepat agar dapat menggunakan kesempatan berkarir yang ada. Proses pengembangan karir meliputi perencanaan karir (career planning) dan manajemen karir (career management). Pengembangan karir dalam sebuah organisasi membutuhkan suatu pemeriksaan atas dua proses tersebut, yaitu bagaimana masing-masing individu merencanakan dan menerapkan tujuantujuan karirnya (perencanaan karir) dan bagaimana organisasi merancang dan menerapkan program-program 
pengembangan karir/manajemen karir. Perencanaan karir (career planning) merupakan suatu proses dimana individu dapat mengidentifikasi dan mengambil langkah-langkah untuk mencapai tujuantujuan karirnya atau suatu usaha yang sengaja dilakukan oleh seseorang untuk menjadi lebih sadar dan tahu akan keterampilannya sendiri, kepentingan, nilai, peluang, hambatan, pilihan, dan akibatakibatnya. Sedangkan Manajemen karir (career management) adalah proses suatu organisasi dalam memilih, menilai, menugaskan, dan mengembangkan para pegawainya guna menyediakan suatu kumpulan orang-orang yang berbobot untuk memenuhi kebutuhan-kebutuhan di masa yang akan datang. Proses ini lebih merupakan usaha formal, terorganisir, dan terencana untuk mencapai keseimbangan antara keinginan karir individu dengan persyaratan tenaga kerja organisasi. Manajemen karir lebih merupakan suatu mekanisme untuk mewujudkan kebutuhan sumber daya manusia masa kini dan masa yang akan datang.

Tujuan pengembangan karir adalah tahap memperbaiki dan meningkatkan efektifitas pekerjaan, agar semakin mampu memberikan kontribusi bagi organisasi /perusahaan. Baiknya pelaksanaan pekerjaan,be rpengaruh pada peluang seseorang pekerja untuk memperoleh posisi/jabatan yang diharapkan. Moekijat (1999) tujuan pengembangan karir adalah sebagai berikut. (1) Untuk mengembangkan keahlian sehingga pekerjaan dapat terselesaikan cepat dan efektif; (2) Untuk mengembangkan pengetahuan sehingga pekerjaan dapat diselesaikan secara rasional; (3) Untuk mengembangkan sikap sehingga menimbulkan kemauan kerja sama dengan teman-teman sesama karyawan dengan pimpinan. Dengan demikian melalui adanya pengembangan karir para karyawan didorong atau dimotivasi agar dapat melaksanakn tugastugasnya secara efektif dan efisien. Sebab semakin efektif dan efisiennya karyawan bekerja akan semakin besar kemungkinan organisasi/perusahaan mencapai tujuan bisnisnya secara maksimal.

Bentuk pengembangan karir
tergantung pada jalur karir yang

direncanakan oleh setiap organisasi. Cara suatu organisasi menentukan jalur karir bagi pegawai yang tergantung pada kebutuhan dan situasi masing-masing organisasi. Seperti yang dikemukakan Handoko (2001), umumnya yang sering dilakukan perusahaan untuk menentukan jalur karir bagi pegawai adalah melalui pendidikan dan pelatihan, promosi serta mutasi. 1) pendidikan dan latihan adalah suatu kegiatan organisasi yang dimaksudkan untuk memperbaiki dan mengembangkan sikap, tingkah laku, keterampilan, dan pengetahuan para pegawai sesuai keinginan dari organisasi yang bersangkutan. 2) promosi jabatan adalah suatu perubahan posisi atau jabatan dari tingkat yang lebih rendah ke tingkat yang lebih tinggi, perubahan ini biasanya akan diikuti dengan meningkatnya tanggung jawab, hak, serta status sosial seseorang. 3) mutasi adalah merupakan bagian dari proses kegiatan yang dapat mengembangkan posisi atau status seseorang dalam suatu organisasi. Sedangkan dalam pengertian yang lebih luas konsep mutasi dirumuskan sebagai suatu perubahan posisi, jabatan, tempat, dan pekerjaan yang dilakukan baik secara horizontal maupun vertikal (promosi atau demosi) di dalam suatu organisasi.

Setiap orang dalam meniti karir pasti akan pernah berada pada posisi tidak ada kemajuan dalam karir dalam setiap organisasi, hanya saja ada orang yang mencapainya lebih awal dari yang lain. Kejadian tersebut sering disebut dengan career plateau (kemandegan karir). Menurut Allen at all, (1999:137), "titik kemandegan dalam karir (career plateau) didefinisikan sebagai suatu titik dalam suatu karir dimana kemungkinan tambahan promosi secara hierarkis sangat rendah". Titik kemandegan dalam karir muncul ketika seorang karyawan mencapai suatu posisi yang tidak mungkin untuk dipromosikan lebih lanjut lagi. Career plateau dapat dilihat secara objektif atau secara subyektif. Secara obyektif dilihat dari lamanya karyawan melebihi batas seharusnya berada pada posisi atau jabatan tertentu untuk naik kejabatan berikutnya. Sedangkan secara subyektif dapat dilihat dari seseorang menerima, menilai dan 
bereaksi tentang perjalanan karirnya. Menurut Allen at all, (1999:137), "penilaian career plateau secara subyektif merupakan persepsi seseorang mengenai karirnya di masa yang akan datang dirasa terbatas atau kecil sekali kemungkinannya untuk dipromosikan".

Seseorang bisa mengalami dua jenis career plateau (kemandegan karir) dalam karirnya. Kedua jenis career plateau (kemandegan karir) tersebut adalah sebagai berikut. 1) Structural (hirarki) plateauing. Structural (hirarki) plateauing terjadi pada saat seseorang punya kesempatan sangat kecil untuk naik ke jenjang yang lebih tinggi dalam organisasi. 2) Job content plateauing. Job content plateauing terjadi saat seseorang tidak tertantang oleh pekerjaan baru dan oleh tanggung jawab pekerjaan. Hal ini disebabkan pada seseorang yang sudah memiliki jabatan tinggi cendrung berfikir untuk tetap pada jabatanya saat ini karena tidak ingin menggambil tanggung jawab yang lebih besar jika berada pada posisi atau jabatan berikutnya. Jika ini sering terjadi pada suatu organisasi, maka akan berakibat pada kinerja pegawai dan rendahnya daya saing organisasi.

Adapun penyebab dari seseorang dalam meniti karirnya mengalami career plateau (kemandegan karir) ada berbagai macam. Menurut Allen at all. (1999), ada tiga faktor penyebab career plateau, yaitu sebagai berikut. (1) Faktor demografi seperti usia, lama bekerja, dan tingkat pendidikan. Karakteristik individu seperti usia, tingkat pendidikan dapat memunculkan career plateau. Pekerja dengan usia tua maupun tingkat pendidikan yang tinggi biasanya telah menduduki jabatan yang tinggi. Pada posisi tersebut kemungkinan untuk naik pada posisi yang lebih tinggi akan berkurang. Kemudian lama bekerja dalam organisasi juga sangat berpengaruh pada pengembangan karir. Masa kerja yang cukup lama dalam organisasi pasti akan mempunyai kesempatan untuk mengembangkan keterampilan karirnya. Dengan demikian semakin rendahnya kesempatan untuk menduduki level yang lebih tinggi dalam struktur organisasi semakin tinggi career plateau yang akan terjadi. (2) Faktor orientasi personal seperti keterlibatan kerja, keinginan untuk belajar, dan eksplorasi karir. Keterlibatan kerja berhubungan dengan pembelajaran dan pengembangan diri. Keterlibatan kerja akan meningkatkan hasil yang diraih berupa gaji atau upah sehingga pekerja lebih termotivasi, lebih produktif, dan berkeinginan untuk belajar lagi. Hal ini akan menjadikan seseorang berpartisipasi dalam pengembangan diri serta termotivasi untuk bereksplorasi karir untuk meningkatkan keterampilan. Dengan demikian semakin tinggi keterlibatan kerja, keinginan untuk belajar, dan eksplorasi karir maka akan semakin kecil career plateau yang dialaminya. (3) Faktor dukungan sosial seperti dukungan atasan. Dukungan atasan juga membantu pegawai. Apabila pegawai tidak meyakini jika mereka mendapat dukungan dari kepala sekolah maka mereka tidak bisa untuk naik ke jenjang yang lebih tinggi dan mereka akan merasa pekerjaannya tidak bermanfaat. Dengan demikian semakin tinggi dukungan atasan maka akan semakin kecil career plateau.

Selain dipengaruhi oleh ke tiga faktor di atas, ada faktor lain yang juga ikut mempengaruhi career plateau (kemandegan karir) seseorang yaitu dari segi finansial. Faktor finansial seperti gaji/upah sangat mempengaruhi kinerja pegawai. Hasibuan (2000:118), menyatakan bahwa "tujuan seseorang bekerja adalah untuk memperbaiki taraf hidup yang didapat dari imbalan atas hasil kerjanya berupa upah atau gaji". Dengan demikian jika hasil yang didapat tidak sesuai dengan pekerjaan yang dilakukan maka akan menimbulkan suatu kesenjangan antara pegawai atau karyawan terhadap perusahaan.

\section{METODE}

Pengumpulan data dilakukan dengan metode kuesioner atau angket. Kuesioner dalam penelitian ini disebarkan kepada 38 responden yang merupakan Populasi seluruh guru pada SMP Negeri 1 Denpasar yang mengalami kemandegan karir. Menurut Arikunto (2005), apabila populasi kurang dari 100 orang, maka sebaiknya semua dijadikan sebagai sasaran penelitian. Oleh karena itu, penelitian ini 
merupakan penelitian populasi atau penelitian sampel jenuh yang artinya semua populasi dijadikan sebagai sasaran penelitian. Sumber data yang digunakan dalam penelitian ini adalah data primer, yaitu data yang diperoleh secara langsung terkait dengan faktor-faktor yang mempengaruhi career plateau (kemandegan karir) guru SMP Negeri 1 Denpasar. Analisis data yang digunakan adalah analisis faktor. Pengujian hipotesis dilakukan dengan menggunakan Statistical Program Social Scence (SPSS) 16.0 for windows dengan menggunakan factor analysis.

\section{HASIL DAN PEMBAHASAN}

Data yang berhasil dikumpulkan dari kuesioner yang disebarkan dan setelah diolah dengan SPSS 16.0 for windows menunjukkan faktor-faktor yang mempengaruhi career plateau (kemandegan karir) guru pada SMP N 1 Denpasar. dapat dijelaskan oleh nilai persentase dari masing-masing faktor. Nilai Total Variance Explained digunakan untuk mengetahui persentase dari kedelapan faktor yang dianalisis. Hasil analisis faktor melalui SPSS menunjukkan persentase dari masing-masing faktor dapat dilihat pada tabel 1 berikut.

Tabel 1. Total Variance Explained

\begin{tabular}{lrrrrrr}
\hline & \multicolumn{3}{c}{ Initial Eigenvalues } & \multicolumn{3}{c}{ Extraction Sums of Squared } \\
\multicolumn{1}{c}{ Component } & \multicolumn{9}{c}{ Loadings } & \\
\cline { 2 - 7 } & Total & $\begin{array}{c}\text { \% of } \\
\text { Variance }\end{array}$ & $\begin{array}{c}\text { Cumulative } \\
\%\end{array}$ & Total & $\begin{array}{c}\text { \% of } \\
\text { Variance }\end{array}$ & $\begin{array}{c}\text { Cumulative } \\
\%\end{array}$ \\
\hline Usia & 2.496 & 31.205 & 31.205 & 2.496 & 31.205 & 31.205 \\
Lama bekerja & 1.425 & 17.818 & 49.023 & 1.425 & 17.818 & 49.023 \\
Tingkat Pendidikan & 1.097 & 13.709 & 62.732 & 1.097 & 13.709 & 62.732 \\
Keinginan Belajar & .931 & 11.637 & 74.369 & & & \\
Eksplorasi Karir & .764 & 9.553 & 83.922 & & & \\
Keterlibatan Bekerja & .577 & 7.218 & 91.140 & & & \\
Dukungan Atasan & .426 & 5.329 & 96.469 & & & \\
Gaji atau Upah & .282 & 3.531 & 100.000 & & & \\
\hline
\end{tabular}

Berdasarkan tabel 1 menunjukkan persentase dari faktor usia memiliki eigenvalue sebesar 2,496 dengan nilai varian sebesar $31,205 \%$, faktor lama bekerja memiliki eigenvalue sebesar 1,425 dengan nilai varian sebesar $17,818 \%$, faktor tingkat pendidikan memiliki eigenvalue sebesar 1,097 dengan nilai varian sebesar $13,709 \%$. Sedangkan faktor keinginan belajar memiliki eigenvalue sebesar 0,931 dengan nilai varian $11,637 \%$, faktor eksplorasi karir memiliki eigenvalue sebesar 0,764 dengan nilai varian 9,553\%, faktor keterlibatan bekerja memiliki eigenvalue sebesar sebesar 0,577 dengan nilai varian $7,218 \%$, faktor dukungan atasan memiliki eigenvalue sebesar 0,426 dengan nilai varian $5,329 \%$, dan faktor gaji atau upah memiliki eigenvalue sebesar 0,282 dengan nilai varian 3,531. Jadi, kedelapan faktor-faktor tersebut mempengaruhi career plateau (kemandegan karir) guru pada SMPN 1 Denpasar. Untuk menjelaskan career plateau (kemandegan karir) guru pada SMPN 1 Denpasar, dapat dilakukan melalui ekstraksi faktor. Ekstraksi faktor dijelaskan oleh total persentase dari masing-masing faktor utama. Faktor-faktor utama tersebut adalah faktor usia, faktor lama bekerja, dan faktor tingkat pendidikan yang memiliki nilai parameter eigenvalue $>1$. Untuk mengetahui distribusi dimensi yang belum dirotasi ke dalam faktor yang telah terbentuk maka dapat dilihat pada output SPSS 16.0 (Rotated Component Matrix). Faktor yang mampu mempengaruhi career plateau (kemandegan karir) guru pada SMP 
N 1 Denpasar, dapat dilihat pada tabel 2 berikut.

Dilihat dari Tabel 2 di atas, dapat dijelaskan bahwa faktor yang memiliki eigenvalue $>1$ adalah usia, lama bekerja, dan tingkat pendidikan, total nilai varianced explained dari ketiga faktor keseluruhan mampu menjelaskan sebesar 62,732\%, dengan demikian $62,732 \%$ dari seluruh faktor yang ada, dapat dijelaskan oleh ketiga faktor yang terbentuk. Usia memiliki varianced explained $31.205 \%$, artinya bahwa usia mampu mempengaruhi kemandegan karir (career plateau) guru sebesar $31.205 \%$. Lama bekerja memiliki varianced explained $17.818 \%$, artinya bahwa lama bekerja mampu mempengaruhi kemandegan karir (career plateau) guru sebesar 17.818\%. Tingkat pendidikan memiliki varianced explained $13.709 \%$, artinya bahwa lama bekerja mampu mempengaruhi kemandegan karir (career plateau) guru sebesar $13.709 \%$.

Tabel 2 Faktor yang Mempengaruhi Career plateau (Kemandegan Karir) Guru

\begin{tabular}{lrrr}
\hline \multicolumn{1}{c}{ Faktor } & Eigenvalue & Varianced Explained $(\%)$ & Factor Loading \\
\hline Usia & 2.496 & 31.205 & .835 \\
Lama Bekerja & 1.425 & 17.818 & .810 \\
Tingkat Pendidikan & 1.097 & 13.709 & .743 \\
Keinginan Belajar & .931 & 11.637 & .863 \\
Eksplorasi Karir & .764 & 9.553 & .750 \\
Keterlibatan Bekerja & .577 & 7.218 & .496 \\
Dukungan Atasan & .426 & 5.329 & .505 \\
Gaji atau Upah & .282 & 3.531 & .832 \\
\hline
\end{tabular}

Menentukan nama faktor yang telah terbentuk untuk masing-masing faktor bersifat subjektif, faktor yang memiliki nilai faktor loading tertinggi digunakan untuk memberi nama faktor. Untuk melihat nilai faktor loading dapat dilihat pada Tabel 3 berikut.

Tabel 3 Rotated Component Matrix

\begin{tabular}{lrrr}
\hline & \multicolumn{4}{c}{ Component } \\
\cline { 2 - 4 } & 1 & 2 & 3 \\
Usia (X1) & .835 & -.172 & -.177 \\
Lama Bekerja (X2) & -.087 & -.159 & .810 \\
Tingkat Pendidikan (X3) & .743 & .069 & -.357 \\
Keinginan Belajar (X4) & .863 & .127 & .224 \\
Eksplorasi Karir (X5) & .162 & .750 & .279 \\
Keterlibatan Bekerja (X6) & .496 & .172 & -.194 \\
Dukungan Atasan (X7) & -.185 & .254 & .505 \\
Gaji atau Upah (X8) & .002 & .832 & -.219 \\
\hline
\end{tabular}

Berdasarkan Tabel 3 di atas, dapat dikelompokan menjadi 3 (tiga) faktor. Faktor 1 (satu) terbentuk dari faktor usia (X1) dengan faktor loading sebesar 0,835, tingkat pendidikan (X3) dengan faktor loading sebesar 0,743 , keinginan belajar (X4) dengan faktor loading sebesar 0,863 dan faktor keterlibatan bekerja (X6) dengan faktor loading sebesar 0,496. Faktor 2 (dua) terbentuk dari faktor eksplorasi karir (X5) dengan faktor loading sebesar 0,750 dan faktor gaji atau upah (X8) dengan faktor loading sebesar 0,832. Faktor 3 (tiga) terbentuk dari faktor lama bekerja (X2) 
dengan faktor loading sebesar 0,810 dan keterlibatan bekerja (X7) dengan faktor loading sebesar 0,505.

Kemudian untuk menentukan dimensi atau faktor yang mempengaruhi career plateau (kemandegan karir) guru paling dominan digunakan parameter koefisien varimax atau mendekati -1 . Nilai yang mendekati 1 diawali oleh nilai 0,5 sedangkan nilai yang mendekati -1 diawali oleh $-0,5$. Secara lebih rinci hasil ringkasan rotasi dari matriks faktor memuat nilai varimax rotation, dapat dilihat pada tabel 4 berikut ini .

Tabel 4. Matriks Rotasi Hasil Analisis Faktor

\begin{tabular}{lccr}
\hline $\begin{array}{c}\text { Dimensi atau faktor } \\
\text { kemandegan karir (career } \\
\text { plateau) }\end{array}$ & \multicolumn{3}{c}{ Varimax Rotation (\%) } \\
\cline { 2 - 4 } & $(1)$ & $(2)$ & (3) \\
\hline Usia & 31,250 & - & 17,818 \\
Lama Bekerja & - & - & - \\
Tingkat Pendidikan & 13,709 & & \\
\hline
\end{tabular}

Berdasarkan tabel 4, maka faktor yang paling dominan mempengaruhi career plateau (kemandegan karir) guru pada SMP N 1 Denpasar adalah faktor usia dengan nilai varimax rotation $31,250 \%$. Artinya kejelasan dari dimensi (kemandegan karir) career plateau guru adalah usia yang paling mendominasi sebesar $31,250 \%$, faktor lama bekerja dengan nilai varimax rotation $17,818 \%$ dan faktor tingkat pendidikan dengan nilai varimax rotation $13,709 \%$.

Career plateau (kemandegan karir) guru pada SMP N 1 Denpasar dipengaruhi oleh faktor usia, lama bekerja, tingkat pendidikan, keinginan belajar, eksplorasi karir, keterlibatan bekerja, dukungan atasan, dan gaji atau upah. Hal ini sesuai dengan teori yang dinyatakan oleh Allen at all, bahwa faktor yang mempengaruhi kemandegan karir ada tiga yaitu faktor demografi, faktor orientasi personal, dan faktor dukungan sosial, untuk mengukur faktor-faktor tersebut sebagai dasar pengukuran kemandegan karir guru yaitu faktor usia, lama bekerja, tingkat pendidikan, keinginan belajar, eksplorasi karir, keterlibatan bekerja, dukungan atasan, dan gaji atau upah. Begitu pula sejalan dengan yang dikatakan oleh Hasibuan bahwa tujuan seseorang bekerja adalah untuk memperbaiki taraf hidup yang didapat dari imbalan atas hasil kerjanya berupa upah atau gaji. Dengan demikian jika hasil yang didapat tidak sesuai dengan pekerjaan yang dilakukan maka akan menimbulkan suatu kesenjangan antara pegawai atau karyawan terhadap perusahaan.

Faktor usia, lama bekerja dan tingkat pendidikan merupakan faktor yang paling dominan mempengaruhi career plateau (kemandegan karir) guru. Faktor ini paling dominan dibandingkan faktor-faktor yang lain disebabkan karena usia tidak hanya mencakup umur yang sudah memasuki masa pensiun, namun berpengaruh terhadap kesehatan dan kecekatan guru dalam melaksanakan pekerjaanya. Banyaknya guru di SMP N 1 Denpasar yang hampir mendekati usia-usia pensiun enggan mengurus kenaikan pangkat atau golongan mereka, karena dirasakan sudah tidak terlalu memberikan kontribusi baik dalam hal kesejahteraan maupun jabatan mereka. Hasil penelitian ini sejalan dengan teori Dessler (2000), pada periode usia empat puluh lima sampai dengan enam puluh lima tahun individu memelihara tujuan dalam dunia kerja yang dilanjutkan dengan usia pensiun, dimana individu menghadapi prospek harus menerima berkurangnya level kekuasaan dan tanggung jawab. 
Faktor lama bekerja merupakan masa kerja mengajar dan beban kerja mengajar selama satu semester yang dimiliki oleh para guru. Sebagian besar guru di SMP Negeri 1 Denpasar yang mandeg di golongan IV/a sudah tersertifikasi dengan diharuskan mengajar dua puluh empat jam per minggu sehingga guru-guru tersebut banyak terkendala pada waktu mengumpulkan dokumen-dokumen yang diperlukan untuk kenaikan pangkat/golongan. Dengan diberikannya beban mengajar tersebut guru merasakan kurangnya waktu untuk berkreativitas khususnya menulis atau melakukan penelitian, terlebih lagi guru-guru yang sudah memiliki masa kerja yang lama cendrung menginjak pada usia pensiun sehingga produktivitas sudah menurun serta kurangnya pengetahuan teknologi komputer dalam proses pembuatan karya ilmiah. Oleh karena itu, guru harus pandai membagi waktu antara tugas di sekolah, keluarga maupun masyarakat. Hasil penelitian ini sejalan dengan teori Manuaba (2000), kerja yang terlalu berlebihan akan menimbulkan kelelahan baik fisik maupun mental. Sedangkan pada kerja yang terlalu sedikit dimana pekerjaan yang terjadi karena pengurangan gerak akan menimbulkan kebosanan dan rasa monoton. Kebosanan dalam kerja rutin sehari-hari karena tugas atau pekerjaan yang terlalu sedikit mengakibatkan kurangnya perhatian pada pekerjaan sehingga secara potensial membahayakan pekerja.

Begitu pula dengan faktor tingkat pendidikan yang merukapan jenjang pendidikan yang dimiliki serta kesesuain mata pelajaran yang diajarkan dengan bidang ilmu yang dimiliki. Guru yang mengajar di SMPN 1 Denpasar, sebagian besar sudah memiliki tingkat pendidikan S1. Namun ada beberapa guru khususnya guru yang sudah memiliki masa kerja lebih dari 28 tahun mengajar mata pelajaran pada bidang yang bukan mereka kuasai, terlebih lagi guru tersebut kurang mengetahui dan memahami teknologi. Dengan demikian mereka mengalami keterbatasan dan kesulitan untuk melakukan proses kenaikan pangkat/golongan yang melalui pengumpulan angka kredit dengan pembuatan karya ilmiah. Keterbatasan kemampuan dalam.

\section{SIMPULAN DAN SARAN}

Berdasarkan hasil analisis data dan pembahasan, maka dapat ditarik simpulan yaitu faktor yang mempengaruhi career plateau (kemandegan karir) guru pada SMP N 1 Denpasar adalah faktor satu usia dengan nilai varian sebesar $31,205 \%$, faktor dua lama bekerja dengan nilai varian sebesar $17,818 \%$, faktor tiga tingkat pendidikan dengan nilai varian sebesar $13,709 \%$, faktor empat keinginan belajar dengan nilai varian $11,637 \%$, faktor lima eksplorasi karir dengan nilai varian 9,553\%, faktor enam keterlibatan bekerja dengan nilai varian $7,218 \%$, faktor tujuh dukungan atasan dengan nilai varian $5,329 \%$, dan faktor delapan gaji atau upah dengan nilai varian $3,531 \%$. Sedangkan faktor yang paling dominan mempengaruhi career plateau (kemandegan karir) guru pada SMP N 1 Denpasar adalah usia yang paling mendominasi sebesar $31,250 \%$, faktor lama bekerja dengan nilai varimax rotation $17,818 \%$ dan faktor tingkat pendidikan dengan nilai varimax rotation $13,709 \%$.

Berdasarkan simpulan yang diperoleh dari hasil penelitian ini, maka dapat dikemukakan saran-saran yaitu bagi guru SMP Negeri 1 Denpasar khususnya guru yang mengalami kemandegan karir, agar dapat memotivasi diri untuk mengurus kenaikan pangkat ke golongan selanjutnya dengan cara melakukan pengembangan keprofesian berkelanjutan. Dan bagi guru yang belum mengalami permasalahan tersebut diharapkan agar tidak mengalami masalah yang sama, sehingga dapat meminimalisasi jumlah guru yang mengalami kemandegan karir khususnya di SMPN 1 Denpasar. Bagi kepala SMP Negeri 1 Denpasar diharapkan agar terus memotivasi dan melakukan evaluasi tentang kinerja guru yang mengalami masalah kemandegan karir, serta memberikan arahan agar guru mau aktif dalam mencari informasi tentang petunjuk teknis proses kenaikan pangkat.

Bagi peneliti lain yang berminat untuk mendalami bidang manajemen sumber daya manusia terkait dengan career plateau (kemandegan karir) guru diharapkan 
melakukan penelitian lebih lanjut dengan beberapa sekolah. Hal ini berguna untuk membandingkan kemandegan yang terjadi di sekolah satu dengan yang lain beserta penyebabnya. Aspek yang perlu dikembangkan dalam penelitian berikutnya adalah mengkaji pengembangan faktorfaktor yang lainnya.

\section{DAFTAR PUSTAKA}

Allen, T.D. Russell.J.E., Poteet, M.L. and Dobbins, G.H. 1999. Belajar dan Pengembangan Job Content Plateauing dalam Perilaku Organisasi. Terjemahan Gina Gania. Learning and Development of Job Content Plateauing Organizational Behaviour. 1980. Jakarta: Erlangga

Arikunto, Suharsimi. 2005. Prosedur Penelitian Edisi Kedua Belas. Jakarta: Rineka Cipta.

Djamilah, Siti. 2005. Analisa Pengaruh Dukungan Atasan, Keterlibatan Kerja, Lama di Organisasi dan Usia pada Job Content Plateauing. Makalah Simposium Nasional Mahasiswa dan Alumni IImu Ekonomi: UGM.

Ghozali, Imam. 2006. Aplikasi Analisis Multivariate Dengan Program SPSS. Cetakan IV. Semarang: Badan Penerbit Universitas Diponegoro.

Handoko, Hani.T. 2001. Manajemen Sumberdaya Manusia. Edisi 2. Jogjakarta: BPFE.

Hasibuan, Drs. H. Malayu, S.P., 2000. Manajemen Sumber Daya Manusia. Edisi Revisi. Jakarta: PT. Bumi Aksara.

Mangkunegara, Anuar Prabu. 2000. Manajemen Sumber Daya Manusia. Bandung: Remaja Rosdakarya.

Mangkuprawira, Sjafri. 2004. Manajemen Sumber Daya Manusia Strategik. Jakarta Selatan: Ghalia Indonesia.

Moekijat. 1999. Manajemen Sumber Daya Manusia (Manajemen. Kepegawaian). Bandung: Mandar Maju.

Muryanta, Rudi. 2010. Menghitung Angka Kredit Guru. Tersedia pada: http://www.wordpress.com/2013/05/m enghitung-angka-kredit-pkg-rudim.pdf/ (diakses tanggal 29 Desember 2013).

Pedoman Penulisan Skripsi dan Tugas Akhir Program Sarjana dan Diploma Departemen Pendidikan Nasional Universitas Pendidikan Ganesha Tahun 2010.

Peraturan Menteri Pendayagunaan Aparatur Negara Dan Reformasi Birokrasi nomor 16 tahun 2009. Tersedia pada: $\mathrm{http}: / / \mathrm{e}-$ dokumen.kemenag.go.id/files/Vq9y3R 2K1286781139.pdf (diakses tanggal 20 Februari 2014).

Peraturan Menteri Pendayagunaan Aparatur Negara nomor 84 tahun 1993. Tersedia pada: http://www.scribd.com/doc/64440631/ KEPMENPAN-84-1993-GURUAK (diakses tanggal 20 Februari 2014).

Preffer, Jeffrey, at all .2002. Paradigma Baru Manajemen Sumber Daya Manusia. Editor A. Usmara, Edisi ke 2. Yogyakarta: Amara Books.

Rachmawati, Ike. K. 2008. Manajemen Sumber Daya Manusia. Yogyakarta: Andi Offset.

Rivai, Vithzal. 2004. Manajemen Sumber Daya Manusia Untuk Perusahaan. Jakarta: PT. Raja Grafindo Persada.

Simamora, H. 2001. Manajemen Sumberdaya Manusia. Edisi 2. Jogjakarta: Badan Penerbit STIE YKPN.

Sugiyono. 2009. Metode Penelitian Kuantitatif Kualitatif dan R\&D. Bandung: Alfabeta.

Wulani, Dewi Sri. 2008. Perencanaan Karir Sebagai Antecedent, dan Sikap Kerja serta Kinerja Sebagai Dampak Career plateau Pada Guru SMP dan SMA Swasta di Surabaya.

Yastarini, Ni Luh Eka. 2012. Analisis Plateau Career (Kemandegan Karir) Guru Pada SMA Negeri 1 Negara (Sebuah Kajian dari Perspektif Manajemen Sumber Daya Manusia): Skripsi Jurusan Pendidikan Ekonomi Universitas. 